\title{
Resource utilization and trophic position of nematodes and harpacticoid copepods in and adjacent to Zostera noltii beds
}

\author{
A.-M. Vafeiadou ${ }^{1,2}$, P. Materatski ${ }^{3}$, H. Adão ${ }^{4}$, M. De $\operatorname{Troch}^{1}$, and T. Moens ${ }^{1}$ \\ ${ }^{1}$ Ghent University, Marine Biology Lab, Department of Biology, Krijgslaan 281/S8, 9000 Ghent, Belgium \\ ${ }^{2}$ Aristotle University of Thessaloniki, School of Biology, Department of Zoology, 54124 Thessaloniki, Greece \\ ${ }^{3}$ University of Évora, School of Sciences and Technology, NemaLab c/o IMAR, Apartado 94, 7002-554 Évora, Portugal \\ ${ }^{4}$ University of Évora, School of Sciences and Technology, CO-CIEMAR c/o NemaLab, Apartado 94, 7002-554 Évora, \\ Portugal
}

Correspondence to: A.-M. Vafeiadou (annamaria.vafeiadou@ugent.be)

Received: 2 December 2013 - Published in Biogeosciences Discuss.: 21 January 2014

Revised: 12 May 2014 - Accepted: 20 June 2014 - Published: 31 July 2014

\begin{abstract}
This study examines the resource use and trophic position of nematodes and harpacticoid copepods at the genus/species level in an estuarine food web in Zostera noltii beds and in adjacent bare sediments using the natural abundance of stable carbon and nitrogen isotopes. Microphytobenthos and/or epiphytes are among the main resources of most taxa, but seagrass detritus and sediment particulate organic matter contribute as well to meiobenthos nutrition, which are also available in deeper sediment layers and in unvegetated patches close to seagrass beds. A predominant dependence on chemoautotrophic bacteria was demonstrated for the nematode genus Terschellingia and the copepod family Cletodidae. A predatory feeding mode is illustrated for Paracomesoma and other Comesomatidae, which were previously considered first-level consumers (deposit feeders) according to their buccal morphology. The considerable variation found in both resource use and trophic level among nematode genera from the same feeding type, and even among congeneric nematode species, shows that the interpretation of nematode feeding ecology based purely on mouth morphology should be avoided.
\end{abstract}

\section{Introduction}

Seagrass meadows form unique, productive and highly diverse ecosystems throughout the world (Hemminga and Duarte, 2000). They stabilize and enrich sediments, and provide breeding and nursery grounds for various organisms as well as critical food resources and habitats for many others (Walker et al., 2001). Seagrass beds typically support higher biodiversity and faunal abundance compared to the adjacent unvegetated areas (Edgar et al., 1994) due to both increased food supply and reduced predation risks (Heck et al., 1989; Ferrell and Bell, 1991). Furthermore, they strongly influence the associated fauna by modifying hydrodynamics (Fonseca and Fisher, 1986) and by altering the energy flux either directly, through release of dissolved organic carbon into the water column, or indirectly, by contributing to the detritus pool after decomposition (Boström and Bonsdorff, 1997).

Several studies during the last decade have used natural stable isotope ratios to elucidate the principal food sources of macrobenthos in seagrass beds, stressing the importance of seagrass-associated sources and/or microphytobenthos (MPB) (Lepoint et al., 2000; Kharlamenko et al., 2001; Moncreiff and Sullivan, 2001; Baeta et al., 2009; Carlier et al., 2009; Lebreton et al., 2011; Ouisse et al., 2012; Vafeiadou et al., 2013a). Less information is available for meiobenthos resource utilization in seagrass beds (Vizzini et al., 2000b, 2002a; Baeta et al., 2009; Leduc et al., 2009; Lebreton et al., 2011, 2012), with none of the studies including meiofauna at the level of feeding types, families, genera or species. The few studies using natural isotope abundances to unravel food resources of coastal meiofauna at this level (Carman and Fry, 2002; Moens et al., 2002, 2005, 2013; Rzeznik-Orignac et al., 2008) do not examine seagrass habitats. 
The present study aims to assess the principal carbon resources of the nematode and harpacticoid copepod assemblages, at the species, genus and family level, in Zostera noltii Hornem. seagrass beds and in adjacent bare sediments. In light of several stable isotope studies which have stressed the predominant role of MPB as a carbon resource to intertidal meiofauna (Moens et al., 2002, 2005; Rzeznik-Orignac et al., 2008; Maria et al., 2012), we hypothesized that MPB would be the principal carbon resource for the majority of taxa in bare sediments. In vegetated sediments, seagrassassociated resources (i.e. seagrass detritus and epiphytes) could also contribute, and higher sedimentation rates would likely raise the contribution of suspended particulate organic matter (SPOM) to meiofauna diets, much like in salt marshes (Moens et al., 2005). We also expected MPB and SPOM to contribute more at the sediment surface than deeper down in the sediment given Rudnick's theory (1989) which proposed a different resource utilization by meiofauna in the sediment surface than in deeper layers: fresh phytodetritus would be the principal resource for nematodes living in the upper $2 \mathrm{~cm}$ of the sediment, whereas deeper down, nematodes would mainly feed on larger fractions of buried, more refractory detritus. Thus, we would expect a higher contribution of detrital organic matter than of MPB or SPOM in deeper sediment layers.

So far, nematodes have been classified in feeding guilds based on buccal morphology (Wieser, 1953; Jensen, 1987; Moens and Vincx, 1997). Nevertheless, stable isotope data and in situ observations of living nematodes have shown that such stoma-morphology based guild classifications do not always provide good predictions of nematode resource utilization and even trophic level (Moens et al., 2005). In harpacticoid copepods, there is also no straightforward link between the morphology of the mouth parts and their food resources (Hicks and Coull, 1983; De Troch et al., 2006). Therefore, we also examined the validity of existing mouth-morphology based nematode feeding guilds, based on their trophic position and resource utilization as revealed by the stable isotope data obtained in this study. If current guild classifications represent real functional groupings, then resource utilization and trophic level within feeding guilds should be very similar, while it would differ between guilds.

\section{Materials and methods}

\subsection{Study area and sampling design}

Sampling was conducted at the Mira estuary $\left(37^{\circ} 40^{\prime} \mathrm{N}\right.$, $8^{\circ} 40^{\prime} \mathrm{W}$, SW Portugal), a small mesotidal system with a semidiurnal tidal regime (amplitude of 1-3 $\mathrm{m}$ during neap and spring tides, respectively). It has a single channel, 5$10 \mathrm{~m}$ deep and up to $400 \mathrm{~m}$ wide, which allows tidal influence to extend $40 \mathrm{~km}$ upstream. Together with the Mira River and its surrounding intertidal area it is included in the pro-

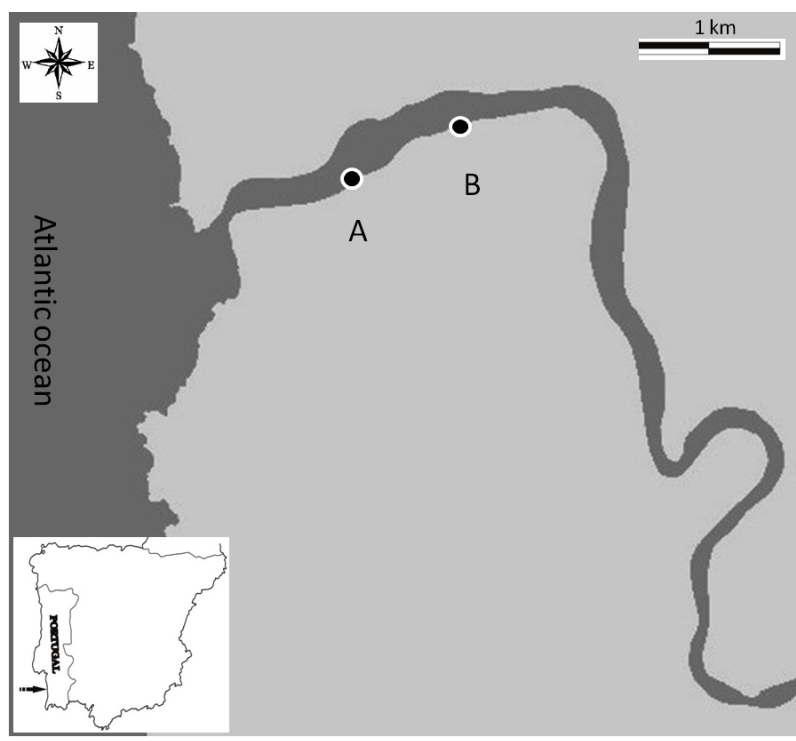

Figure 1. Map of the study area: Mira estuary (Portugal) and sampling sites (A and $\mathbf{B})$.

tected Sudoeste Alentejano e Costa Vicentina natural park (Fig. 1). This estuary is considered relatively undisturbed and free from industrial pollution (Costa et al., 2001). Our study area was located at two sites of the intertidal area at the lower section, ca. $1.5 \mathrm{~km}$ from the mouth of the estuary (i.e. sampling site A) and ca. $2 \mathrm{~km}$ further upstream (i.e. sampling site B). Due to the low, seasonal and limited freshwater input, the lower section of the estuary has a significant marine signature. In both sites, sediments were sparsely covered with Zostera noltii; seagrass vegetation was less dense (ca $50 \%$ difference) in February 2011 than in June 2010 (Vafeiadou et al., 2013a). These seagrass beds used to be denser in the past, but the vegetation is under recovery after a major collapse in 2008 (Adão et al., 2009; Cunha et al., 2013). Samples were collected on two instances (22 June 2010 and 7 February 2011), during low tide (tidal amplitude of $3 \mathrm{~m}$ ). We sampled two random stations at each sampling site (i.e. A and B), one located inside the seagrass vegetation (i.e. A1 and B1) and the other in adjacent bare sediments (i.e. A2 and B2).

\subsection{Sampling of carbon resources and meiobenthos}

Fresh seagrass leaves, roots and seagrass detrital material were collected randomly from each vegetated station (i.e. A1 and B1), thoroughly rinsed and carefully scraped off using a cover glass to remove epiphytes, which were collected separately. To obtain bulk sediment organic matter we sampled three replicate cores $\left(10 \mathrm{~cm}^{2}\right)$ of the upper $6 \mathrm{~cm}$ of sediment from all stations. The epipelic fraction of MPB was collected via migration through the lens tissue method (Eaton and Moss, 1966) 1 year later than the other samples, but at very similar sampling times and conditions (February and June 2012) because samples collected during the 2010/2011 
campaigns yielded insufficient MPB biomass for reliable nitrogen isotopic analysis. $1.5 \mathrm{~L}$ of seawater was filtered over pre-combusted Whatman GF/F filters to collect SPOM. Seagrass material and bulk sediment samples were oven dried $\left(60^{\circ} \mathrm{C}\right)$ for $48 \mathrm{~h}$ before preservation and stored in desiccators; all other samples were stored frozen.

Meiobenthos samples were obtained by forcing hand cores $\left(10 \mathrm{~cm}^{2}\right)$ to a depth of $6 \mathrm{~cm}$ into the sediment at all stations. Each sediment sample was divided into three depth layers: 02, 2-4 and 4-6 cm. Seven replicate samples were randomly collected from each station within a $100 \mathrm{~m}^{2}$ area and then pooled into one bulk sample considered representative for a particular station. Pooling of replicate samples was done to ensure that enough biomass of several genera/species could be obtained for the stable isotope analyses. Meiobenthos samples were stored frozen prior to elutriation and analysis.

\subsection{Preparation of samples for stable isotope analyses}

Dried seagrass and bulk sediment samples were homogenised, weighed $(0.3-0.7 \mathrm{mg}$ dry weight of seagrass, $20-60 \mathrm{mg}$ dry weight of sediment) and transferred into silver cups $(8 \times 5 \mathrm{~mm}$, Elemental Microanalysis Ltd $)$ which had been pre-treated for $4 \mathrm{~h}$ at $550^{\circ} \mathrm{C}$ to remove organic contamination. Two subsamples were then prepared: the first was acidified with dilute $\mathrm{HCl}$ to remove carbonates, the second was not acidified, to eliminate any effects of acidification on nitrogen isotopic signatures (Vafeiadou et al., 2013b). A drop of milli-Q water was added to acidified samples which then were oven dried $\left(60^{\circ} \mathrm{C}\right)$ for $48 \mathrm{~h}$. Epiphyte and MPB samples were all acidified since insufficient biomass was available for subsampling. The Whatman GF/F filters were divided in two; only one half was acidified under $\mathrm{HCl}$ vapour for $24 \mathrm{~h}$, the other not. All samples were prepared in pre-combusted silver cups.

Meiofauna was elutriated using density centrifugation in Ludox HS40 colloidal silica, which does not affect isotope signatures (Moens et al., 2002). No other chemicals were used during processing of the meiofauna samples. The most abundant nematode and copepod taxa were hand-sorted and identified at the genus or family level under a stereomicroscope. Individuals were hand-picked with a fine needle, rinsed several times in milli-Q water to remove adhering particles, and finally transferred into a drop of milli-Q water in pre-combusted aluminium cups $(6 \times 2.5 \mathrm{~mm}$, Elemental Microanalysis Ltd). The number of specimens transferred into the cups depended on the abundance and individual biomass of the different taxa. We aimed at a sample mass $>5 \mu \mathrm{g}$ for the element of interest, be it $\mathrm{C}, \mathrm{N}$ or both. Thus, 10-40 individuals were pooled together for a copepod sample and 10-300 for a nematode sample, depending on their size. In many cases though, the biomass of the sample was sufficient only for reliable carbon analysis but not for nitrogen analysis. Thus, despite the combined $\delta^{13} \mathrm{C} / \delta^{15} \mathrm{~N}$ analysis per sample, we finally obtained different sample numbers for the $\delta^{13} \mathrm{C}$ and $\delta^{15} \mathrm{~N}$ data. Because of very low meiofauna abundances below a depth of $2 \mathrm{~cm}$, for most taxa at this depth we obtained sufficient biomass for only a single isotope measurement.

\subsection{Stable isotope analyses}

Isotopic analyses of resources and meiofauna were performed using a ThermoFinnigan Flash 1112 elemental analyser (EA) coupled online via a Conflo III interface to a ThermoFinnigan Delta Plus XL isotope ratio mass spectrometer (IRMS), with analytical reproducibility typically $\leq 0.2 \%$ ofor both $\delta^{13} \mathrm{C}$ and $\delta^{15} \mathrm{~N}$. All resource samples were measured in He-dilution mode, except for the epiphyte samples. These, as well as all meiofauna samples, were measured without $\mathrm{He}$ dilution. Stable isotope ratios are expressed in units of parts per thousand, according to the formula:

$\delta X=\left(R_{\text {sample }} / R_{\text {standard }}-1\right) \times 10^{3}$,

where $X$ is ${ }^{13} \mathrm{C}$ or ${ }^{15} \mathrm{~N}$ and $R$ the ratio of ${ }^{13} \mathrm{C} /{ }^{12} \mathrm{C}$ or ${ }^{15} \mathrm{~N} /{ }^{14} \mathrm{~N}$. As external lab standards, we used CH-6 (sucrose) and N1 (ammonium sulfate) from the International Atomic Energy Agency, with $\delta^{13} \mathrm{C}$ and $\delta^{15} \mathrm{~N}$ values of -10.4 and $+0.4 \%$, respectively.

When measuring samples containing limited biomass, caution is needed when assessing the results of IRMS. Based on prior tests with decreasing mass of standards of known isotopic ratios, we discarded all results of samples yielding amplitudes smaller than $200 \mathrm{mV}$. We measured external standards for linear corrections of small analytical errors in the obtained $\delta$-values. Further, we routinely corrected the obtained sample $\delta$-values for the contribution of blanks using the formula:

$\delta_{\text {organic matter }}=\left(\delta_{\text {sample }} \times\right.$ amplitude $_{\text {sample }^{-}}$

$\delta_{\text {blank }} \times$ amplitude $\left._{\text {blank }}\right) /$ amplitude $_{\text {organic matter }}$,

where $\delta_{\text {organic matter }}$ is the real $\delta$-value of the material of interest and amplitude organic matter $=$ amplitude $_{\text {sample }}$

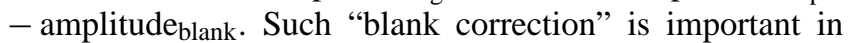
samples with low amplitudes, where even small blanks may contribute significantly to the measured $\delta_{\text {sample }}$ (Moens et al., 2013).

\subsection{Data analysis}

For the interpretation of stable isotope data and for mixing model computations, trophic enrichment factors of $1 \pm 1.2 \%$ for $\delta^{13} \mathrm{C}$ and $2.5 \pm 2.5 \%$ for $\delta^{15} \mathrm{~N}$ were adopted for each trophic step (Vander Zanden and Rasmussen, 2001). The comparison of stable isotope data of meiobenthos between vegetated and bare sediments was performed using paired Student's $t$ tests. For this comparison we used only $\delta^{13} \mathrm{C}$ data of those taxa which occurred in the upper $2 \mathrm{~cm}$ of both types of sediments. Data from deeper layers and of $\delta^{15} \mathrm{~N}$ were not included in this analysis because of a lack of sufficient replication. No data transformation was applied since 
the assumptions of normality and homoscedasticity (tested by Cochran's test) were met. The validity of the comparison, with type of sediment as the only factor, was based on the fact that resource isotope signatures did not differ across months or stations (Vafeiadou et al., 2013a). These univariate statistical analyses were performed using Statistica 6 software (StatSoft).

The Bayesian stable isotope mixing model MixSIR (Semmens and Moore, 2008; MixSIR Version 1.0.4. for MATLAB, R2013a, The MathWorks) was applied to the present data, to calculate the relative contributions of potential food resources to the diets of meiofauna. We used the following input data for consumers: $\delta^{13} \mathrm{C}$ and $\delta^{15} \mathrm{~N}$ of each replicate sample separately per taxon, only including data of those samples for which we obtained both $\delta^{13} \mathrm{C}$ and $\delta^{15} \mathrm{~N}$. Input data for potential resources were: mean and SD of $\delta^{13} \mathrm{C}$ and of $\delta^{15} \mathrm{~N}$ of all replicate samples per resource. Seagrass leaves were excluded from the model because meiofauna are unlikely to graze directly on living seagrass tissue, both because of the limited direct physical contact between endobenthic meiofauna and living seagrass leaves and because of the absence of any reports showing that meiofauna can graze on living macrophyte tissue. Seagrass detritus, however, was included as a candidate resource; it is unclear whether meiofauna can directly utilize macrophyte detritus, but they are certainly capable of grazing on micro-organisms which decompose the detritus (Moens and Vincx, 1997; Cnudde et al., 2013) and which may have almost identical carbon isotope ratios (Boschker et al., 1999). Seagrass roots were also considered as a potential resource; although they might not be directly grazed upon by meiofauna, they may indirectly contribute to the food web via root exudates consumed by microbiota, even though this link was not detectable in a study on Zostera marina (Boschker et al., 2000). Seagrass roots and detritus were pooled as one "seagrass resource" by calculating the mean and SD of their isotopic signatures. We did the same for epiphytes and MPB. In both cases, isotopic ratios of both resources strongly overlapped, hampering adequate assignment of the contribution of each resource separately by the mixing model. A higher number of potential resources also bears upon the performance of the isotope mixing model (Parnell et al., 2010; Middelburg, 2014). Although not measured here, chemoautotrophic bacteria were added as an additional resource based on the $\delta^{13} \mathrm{C}$ obtained here for the nematode genera Terschellingia and Sabatieria and for the copepod family Cletodidae and on literature information (see the discussion); we adopted an average $\delta^{13} \mathrm{C}$ of $-35 \pm 5 \%$ for this resource (based on data for sulfideoxidizing bacteria in Robinson and Cavanaugh, 1995) and an average $\delta^{15} \mathrm{~N}$ of $4 \pm 0.5 \%$, based on our own data for the three aforementioned taxa, since we found no information on the $\delta^{15} \mathrm{~N}$ of sulfide-oxidizing bacteria in the literature. We ran MixSIR with 10000 iterations, without resource contribution data defined a priori. The model was applied separately for seagrass beds and bare sediments, and for the surface and deeper sediment layers.

\section{Results}

\subsection{Stable isotope signatures of meiobenthos}

Overall, the present study includes $\delta^{13} \mathrm{C}$ data of 20 nematode taxa, 16 of which were identified to the genus level (two genera were represented by two species each) and two to the family level (unidentified Comesomatidae and Chromadoridae), as well as four harpacticoid copepod families (Canuellidae, represented here by the genus Sunaristes, Cletodidae, Ectinosomatidae and Harpacticidae, this last taxon being present only in deeper sediments) (Tables 1 and 2). The $\delta^{15} \mathrm{~N}$ data are available for 8 of the 16 nematode genera and the unidentified Comesomatidae, and for two copepod families (Canuellidae and Cletodidae) (Tables 1 and 2). Although this data set includes most of the abundant genera of this nematode assemblage (Table 1), some abundant genera are not represented here because of their low individual biomass, hampering the collection of sufficient biomass for stable isotope analysis.

The $\delta^{13} \mathrm{C}$ of most meiofauna from the upper $2 \mathrm{~cm}$ ranged from $-22.7 \pm 1.2 \%$ (Spirinia parasitifera) to $-11.9 \%$ o (Theristus) (Fig. 2a), and $\delta^{15} \mathrm{~N}$ ranged from 3.9\%o (Sunaristes) to $10.8 \%$ (Comesomatidae) (Fig. 2b). The nematode genus Terschellingia and the copepod family Cletodidae had much lower $\delta^{13} \mathrm{C}$ (mean $\delta^{13} \mathrm{C} \pm \mathrm{SD}=-41.7 \pm 2.4 \%$ and $-33.2 \pm 5.5 \%$, respectively; Fig. 2 a) compared to all other meiofauna. Terschellingia also had very low $\delta^{15} \mathrm{~N}$ values $\left(2.8 \pm 1.9 \%\right.$; Fig. 2b). Most taxa had $\delta^{13} \mathrm{C}$ in the range of MPB and epiphytes, whereas Spirinia parasitifera and Sabatieria sp. 2 were more depleted in ${ }^{13} \mathrm{C}$, with $\delta^{13} \mathrm{C}$ values close to SPOM (-24.1 $\pm 1.2 \%$; Figs. 2a and 3). Daptonema, Metachromadora, Spirinia sp. 2, Ptycholaimellus and Theristus were comparatively enriched in ${ }^{13} \mathrm{C}$, with values close to those of seagrass detritus $(-16.0 \pm 1.1 \%$; Figs. 2a and 3). The comparison of $\delta^{13} \mathrm{C}$ of meiobenthos from the surface sediment layers between vegetated and bare sediments did not reveal any significant differences $(d f=32$, $t=1.35 ; p>0.05)$. The $\delta^{15} \mathrm{~N}$ data clearly show the presence of more than one trophic level in this nematode assemblage in the upper $2 \mathrm{~cm}$, with Sphaerolaimus, Paracomesoma and unidentified Comesomatidae belonging to a higher trophic level than all other meiofauna (Figs. 2b and 3).

The $\delta^{13} \mathrm{C}$ and $\delta^{15} \mathrm{~N}$ data from the deeper sediment layers $(2-6 \mathrm{~cm})$ are available for a lower number of nematode and copepod taxa due to the overall low meiofauna abundances in these deeper layers (Table 2). Most $\delta^{13} \mathrm{C}$ ranged from $-29.8 \%$ (Paracanthonchus) to $-14.4 \pm 0.4 \%$ (Metachromadora), with the exception of Terschellingia and Cletodidae, which had much lower $\delta^{13} \mathrm{C}(-40.4 \pm 4.5 \%$ and $-33.5 \%$, respectively; Table 2). The $\delta^{13} \mathrm{C}$ of most taxa in 
A

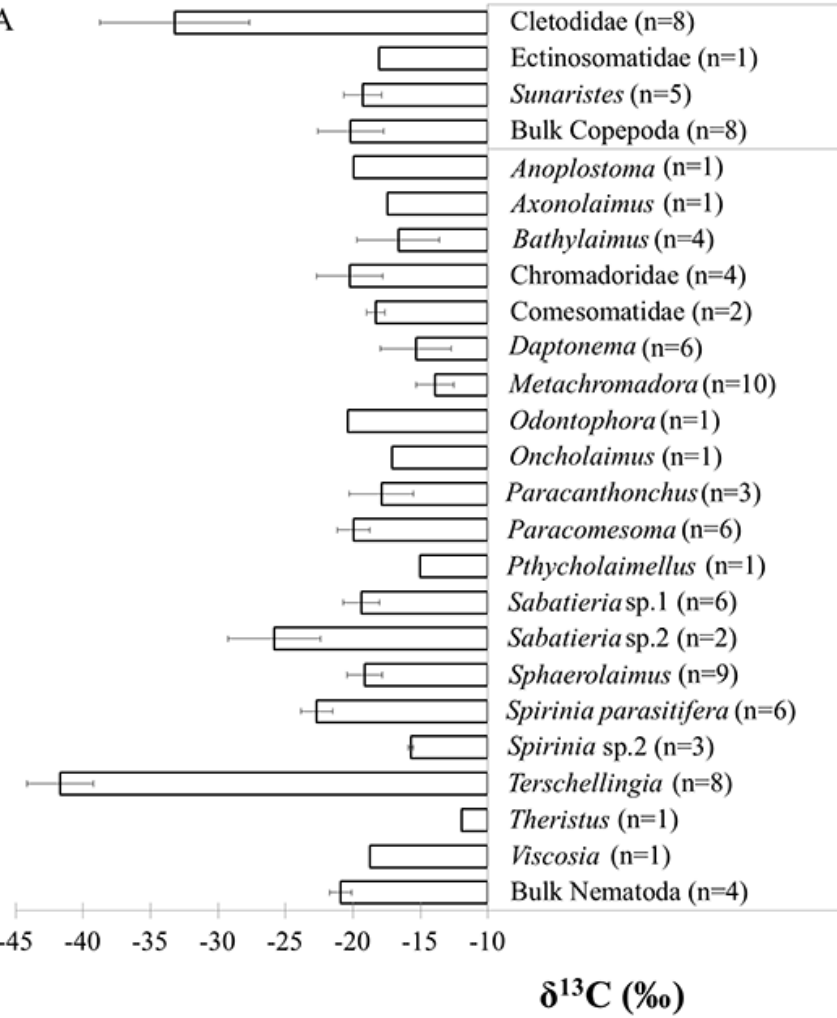

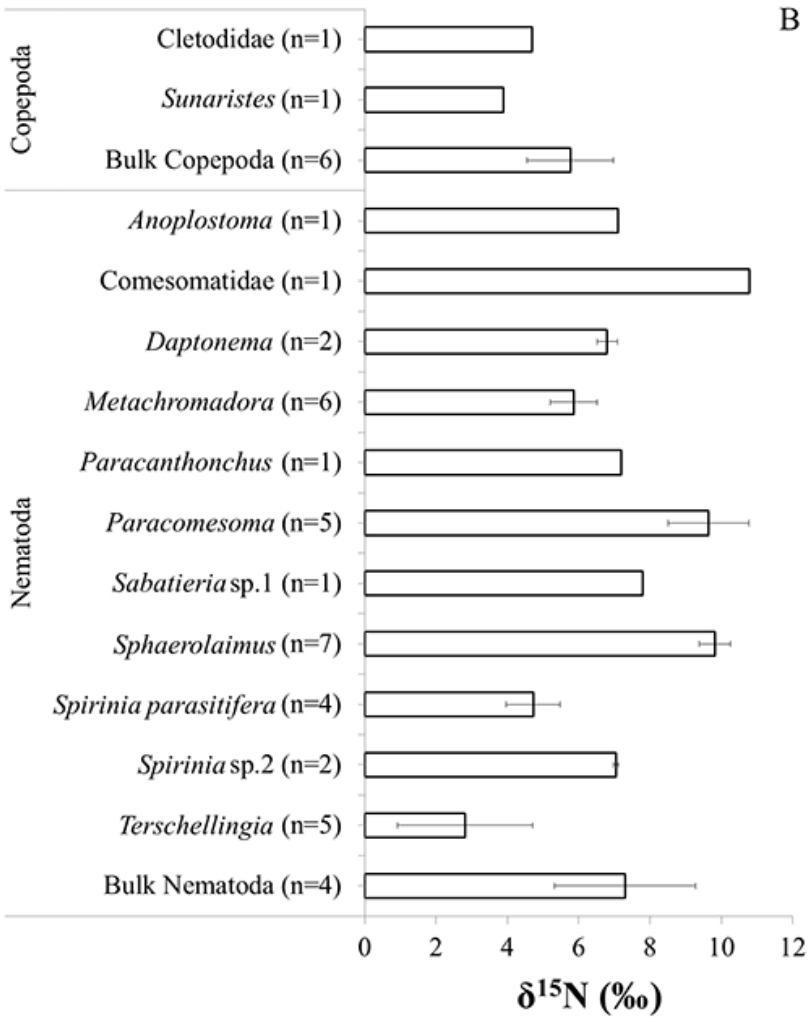

B

Figure 2. Stable carbon (A) and nitrogen (B) isotope signatures of meiobenthos from the upper $2 \mathrm{~cm}$. Data are mean values $( \pm \mathrm{SD})$ of all replicate samples per taxon, from both vegetated and bare stations ( $n=$ number of replicate samples).

the deeper sediment layers (i.e. Anoplostoma, Bathylaimus, Oncholaimus, Paracanthonchus, Sphaerolaimus and Spirinia parasitifera) were more ${ }^{13} \mathrm{C}$-depleted (by $>4 \%$ ), and closer to those of SPOM than those from the same taxa at the sediment surface, where they had more intermediate values. The $\delta^{13} \mathrm{C}$ of Oncholaimus, Paracanthonchus, Sabatieria sp. 2, Spirinia parasitifera and Harpacticidae were even more depleted than any other measured resource. In contrast, $\delta^{13} \mathrm{C}$ of the nematodes Daptonema, Metachromadora and Spirinia sp. 2 and of the copepod genus Sunaristes were in the range of values for seagrass detritus, epiphytes and/or MPB (Table 2).

\subsection{Application of the isotope mixing model MixSIR}

Applying the isotope mixing model MixSIR to our data yielded model estimations of the proportional contributions of each resource to the diet of each nematode genus/species or copepod family/genus, in seagrass vegetated and bare sediments, and in surface and deeper layers (Table 3). Seagrassderived carbon (detritus and/or roots) contributed more than other resources to the requirements of Metachromadora: 0.75 $(0.60-0.88)$ in seagrass beds and $0.85(0.70-0.95)$ in bare sediments, as well as of Daptonema with contributions of $0.70(0.48-0.87)$ and $0.71(0.31-0.89)$ and of Spirinia sp. 2 with contributions of $0.59(0.28-0.81)$ and $0.67(0.25-0.86)$, in seagrass beds and in bare sediments, respectively (proportional contributions per unit are given as median and lower to upper limits of $95 \%$ confidence intervals; Table 3). Suspended particulate organic matter contributed predominantly to the requirements of Sphaerolaimus: $0.27(0.02-0.75)$ and 0.20 (0.01-0.72), of Paracomesoma: $0.29(0.03-0.73)$ and $0.39(0.02-0.78)$ and of Spirinia parasitifera: $0.37(0.25-$ 0.78 ) and $0.34(0.02-0.76)$, in seagrass beds and in bare sediments, respectively (Table 3); nevertheless, seagrass resources and chemoautotrophic bacteria also contributed substantially to the diet of the aforementioned taxa. The very wide range of contributions covered by the $95 \%$ confidence intervals is largely a result of including the very ${ }^{13} \mathrm{C}$-depleted chemoautotrophic bacteria as a candidate resource. In addition, if chemoautotrophic bacteria are not included as a resource in the model, the contribution of SPOM to the diets of several taxa substantially increases. For example, running MixSIR for the three taxa above without chemoautotrophic bacteria as a potential resource yielded SPOM contributions for Sphaerolaimus, Paracomesoma and Spirinia parasitifera of 0.77 (0.64-0.89), $0.80(0.66-0.92)$ and $0.83(0.69-0.94)$, respectively, in seagrass vegetation, and of $0.67(0.50-0.83)$, $0.72(0.57-0.86)$ and $0.79(0.65-0.93)$, respectively, in bare sediments. Microphytobenthos and/or epiphytes contributed substantially to the diet of most nematode and copepod 
Table 1. Relative abundance $(\%)$ of nematode genera in Zostera noltii beds and stable isotope data of the potential carbon resources and meiofauna from the upper $2 \mathrm{~cm}$ in seagrass beds and bare sediments $(n=$ number of replicate samples).

\begin{tabular}{|c|c|c|c|c|c|c|c|c|c|c|}
\hline \multirow[t]{2}{*}{ Meiofauna } & \multicolumn{2}{|c|}{ Rel. abundance (\%) } & \multicolumn{4}{|c|}{ Mean $\delta^{13} \mathrm{C} \pm \mathrm{SD}(\% \circ)$} & \multicolumn{4}{|c|}{ Mean $\delta^{15} \mathrm{~N} \pm \mathrm{SD}(\% \circ)$} \\
\hline & June & Feb & $n$ & Seagrass beds & $n$ & Bare sediments & $n$ & Seagrass beds & $n$ & Bare sediments \\
\hline \multicolumn{11}{|l|}{ NEMATODA } \\
\hline Anoplostoma & 0.69 & 0.74 & 1 & -19.9 & & & 1 & 7.1 & & \\
\hline Axonolaimus & 1.25 & 5.10 & & & 1 & -17.4 & & & & \\
\hline Bathylaimus & 0.29 & 0.35 & 3 & $-16.7 \pm 3.7$ & 1 & -16.5 & & & & \\
\hline Chromadoridae & & & 4 & $-20.2 \pm 2.5$ & & & & & & \\
\hline Comesomatidae & & & 2 & -18.3 & & & 1 & 10.8 & & \\
\hline Daptonema & 3.78 & 7.71 & 2 & -15.7 & 4 & $-15.1 \pm 2.8$ & 1 & 7 & 1 & 6.6 \\
\hline Metachromadora & 2.29 & 4.37 & 5 & $-13.9 \pm 1.6$ & 5 & $-13.8 \pm 1.5$ & 4 & $5.9 \pm 0.8$ & 2 & 5.8 \\
\hline Odontophora & 8.53 & 6.61 & & & 1 & -20.4 & & & & \\
\hline Oncholaimus & 1.96 & 0.59 & 1 & -17.1 & & & & & & \\
\hline Paracanthonchus & 0.33 & 0.01 & 2 & -17.2 & 1 & -19.2 & 1 & 7.2 & & \\
\hline Paracomesoma & 8.36 & 21.87 & 2 & -21.2 & 4 & $-19.4 \pm 0.9$ & 2 & 10.7 & 3 & $8.9 \pm 0.8$ \\
\hline Pthycholaimellus & 10.97 & 1.48 & & & 1 & -15.0 & & & & \\
\hline Sabatieria sp. 1 & 4.04 & 3.03 & 2 & -20.6 & 4 & $-18.8 \pm 1.2$ & 1 & 7.8 & & \\
\hline Sabatieria sp. 2 & 4.04 & 3.03 & 1 & -23.4 & 1 & -28.3 & & & & \\
\hline Sphaerolaimus & 2.71 & 4.89 & 5 & $-19.5 \pm 1.4$ & 4 & $-18.7 \pm 1.3$ & 4 & $10.1 \pm 0.1$ & 3 & $9.4 \pm 0.3$ \\
\hline Spirinia parasitifera & 10.17 & 5.15 & 3 & $-18.6 \pm 3.4$ & 3 & $-23.3 \pm 1.6$ & 2 & 4.6 & 2 & 4.8 \\
\hline Spirinia sp. 2 & 10.17 & 5.15 & 2 & -15.6 & 1 & -15.9 & 1 & 7.1 & 1 & 7 \\
\hline Terschellingia & 18.13 & 25.33 & 4 & $-40.9 \pm 3.39$ & 4 & $-42.4 \pm 1.1$ & 2 & 3.5 & 3 & $2.3 \pm 2.5$ \\
\hline Theristus & 0.01 & 0.01 & 1 & -12.0 & & & & & & \\
\hline Viscosia & 0.86 & 0.80 & 1 & -18.8 & & & & & & \\
\hline Bulk Nematoda & & & 2 & -20.8 & 2 & -21.0 & 2 & 8.9 & 2 & 5.6 \\
\hline \multicolumn{11}{|l|}{ COPEPODA } \\
\hline Cletodidae & & & 4 & $-30.9 \pm 3.3$ & 4 & $-35.5 \pm 6.8$ & 1 & 4.7 & & \\
\hline Ectinosomatidae & & & & & 1 & -18.1 & & & & \\
\hline Sunaristes (Canuellic & & & 1 & -19.8 & 4 & $-19.2 \pm 1.6$ & & & 1 & 3.9 \\
\hline Bulk Copepoda & & & 5 & $-21.7 \pm 1.7$ & 3 & $-19.2 \pm 2.5$ & 4 & $6.3 \pm 0.8$ & 2 & 4.7 \\
\hline \multicolumn{3}{|c|}{ Carbon resource } & $n$ & \multicolumn{3}{|c|}{ Mean $\delta^{13} \mathrm{C} \pm \mathrm{SD}(\% \circ)$} & \multicolumn{4}{|c|}{ Mean $\delta^{15} \mathrm{~N} \pm \mathrm{SD}(\% \circ)$} \\
\hline \multicolumn{3}{|l|}{ Seagrass fresh leaves } & 8 & \multicolumn{3}{|c|}{$-11.4 \pm 0.7$} & \multicolumn{4}{|c|}{$3.7 \pm 2.1$} \\
\hline \multicolumn{3}{|l|}{ Seagrass roots } & 8 & \multicolumn{3}{|c|}{$-12.9 \pm 0.4$} & \multicolumn{4}{|c|}{$3.2 \pm 0.7$} \\
\hline \multicolumn{3}{|l|}{ Seagrass detritus } & 4 & \multicolumn{3}{|c|}{$-15.9 \pm 1.1$} & \multicolumn{4}{|c|}{$3.6 \pm 0.4$} \\
\hline \multicolumn{3}{|c|}{ Epiphytes } & 6 & \multicolumn{3}{|c|}{$-18.8 \pm 1.8$} & \multicolumn{4}{|c|}{$5.2 \pm 0.7$} \\
\hline \multicolumn{3}{|c|}{ Microphytobenthos (MPB) } & 11 & \multicolumn{3}{|c|}{$-19.9 \pm 1.3$} & \multicolumn{4}{|c|}{$7.6 \pm 1.6$} \\
\hline Bulk sediment organic & $\operatorname{er}(S O M$ & & & & & & & & & \\
\hline $0-2 \mathrm{~cm}$ depth layer & & & 16 & -2 & $.1 \pm$ & 17.7 & & $4.7=$ & 0.2 & \\
\hline $2-4 \mathrm{~cm}$ depth layer & & & 16 & & $0.9 \pm$ & 0.8 & & $5.2=$ & 0.8 & \\
\hline $4-6 \mathrm{~cm}$ depth layer & & & 16 & & $.8 \pm$ & 0.7 & & 5.5 & 0.2 & \\
\hline Suspended particulate & nic matt & $O M)$ & 17 & & $1.1 \pm$ & 1.2 & & $5.1=$ & 1.7 & \\
\hline
\end{tabular}

taxa with intermediate stable carbon isotope signals (Table 3). Chemoautotrophic bacteria contributed to the carbon requirements of Terschellingia for 0.91 (0.83-0.97) and $0.93(0.86-0.97)$ in seagrass beds and in bare sediments, respectively (Table 3 ). It also predominantly contributed to the diet of Cletodidae: for $0.55(0.39-0.74)$ in seagrass beds. In the latter, however, SPOM and MPB/epiphyte contributions were also substantial. The limited available data do not allow mixing model computations for Sabatieria sp. 2, although its $\delta^{13} \mathrm{C}$ data suggest at least partly chemoautotrophic carbon utilization. Nevertheless, the contribution of the latter resource to the requirements of another species of the same genus, Sabatieria sp. 1, was predicted to be low 0.14 (0.020.32 ) in seagrass beds; Table 3 ).

\section{Discussion}

\subsection{Resource utilization by meiobenthos inside and adjacent to Zostera vegetation}

The stable isotope data of resources and consumers obtained in this study suggest that seagrass detritus and roots, epiphytes, MPB and SPOM all contribute in varying degrees to the carbon requirements of meiofauna. In all, the 
A

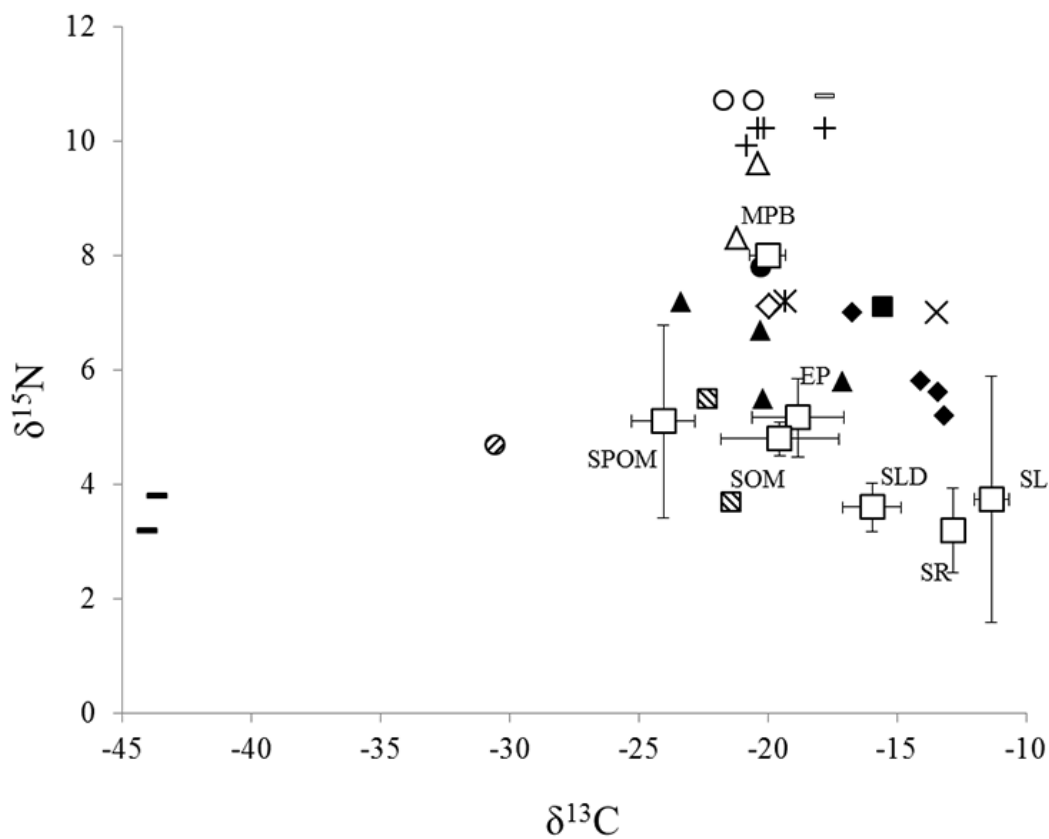

B

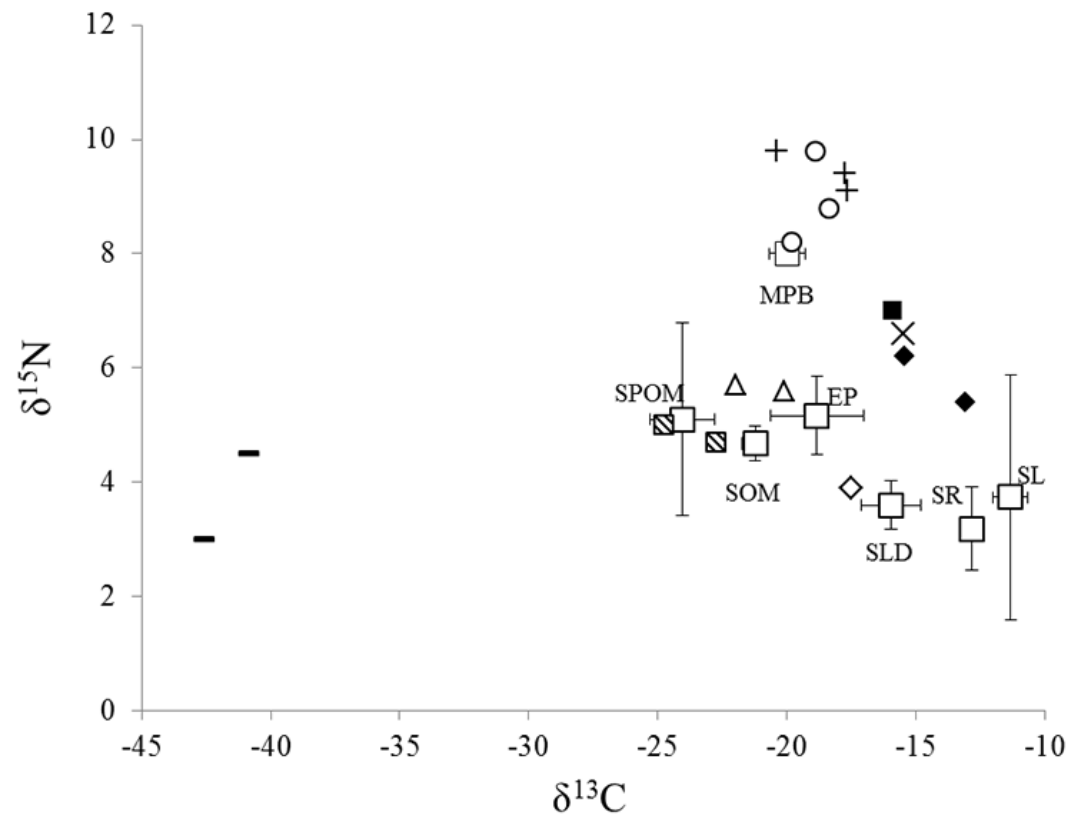

$\diamond$ Anoplostoma

-Comesomatidae

$\times$ Daptonema

- Metachromadora

* Paracanthonchus

OParacomesoma

- Sabatieria sp.1

+Sphaerolaimus

$\mathbf{Q}$ Spirinia parasitifera

- Spirinia sp.2

-Terschellingia

$\oslash$ Cletodidae

$\triangle$ Bulk Nematoda

$\Delta$ Bulk Copepoda $\times$ Daptonema

- Metachromadora

oParacomesoma

+ Sphaerolaimus

$\mathbb{\$}$ Spirinia parasitifera

- Spirinia sp.2

$\diamond$ Sunaristes

$\triangle$ Bulk Nematoda

- Terschellingia

Figure 3. Biplots of $\delta^{13} \mathrm{C} / \delta^{15} \mathrm{~N}$ of meiobenthos from the upper $2 \mathrm{~cm}$ and their potential resources in seagrass beds (A) and bare sediments (B). Resource data are mean values $( \pm \mathrm{SD})$ of all replicate samples per source material. Abbreviations used: SL, SR and SLD for seagrass leaves, roots and detritus, respectively; EP for epiphytes, MPB for microphytobenthos, SPOM for suspended particulate organic matter and SOM for bulk sediment organic matter.

proportional contributions estimated by the isotope mixing model MixSIR agree well with our data interpretation based on the isotope biplots, despite their often wide range, given the large confidence intervals adopted for calculating the most probable model solutions. No significant differences in isotope signatures of nematode and copepod taxa inside seagrass vegetation compared to in adjacent bare sediments were detected, contradicting our hypothesis that MPB would contribute more in bare sediments, whereas seagrass detritus and SPOM would be more important resources inside vegetated sediments. This agrees well with results for macrobenthos from the same ecosystem (Vafeiadou et al., 2013a). Seagrass vegetation has important indirect effects on resource availability, for instance, through substrate 
Table 2. Mean $( \pm \mathrm{SD})$ stable isotope signatures of meiofauna from the deeper sediment layers $(2-6 \mathrm{~cm})$, from all stations $(n=$ number of replicate samples).

\begin{tabular}{|c|c|c|c|c|}
\hline Meiofauna & $n$ & $\delta^{13} \mathrm{C} \pm \mathrm{SD}(\% \circ)$ & $n$ & $\delta^{15} \mathrm{~N} \pm \mathrm{SD}(\% o)$ \\
\hline \multicolumn{5}{|l|}{ NEMATODA } \\
\hline Anoplostoma & 2 & $-21.6 \pm 0.1$ & & \\
\hline Bathylaimus & 1 & -22.6 & & \\
\hline Daptonema & 2 & $-17.5 \pm 2.3$ & & \\
\hline Metachromadora & 2 & $-14.4 \pm 0.4$ & & \\
\hline Oncholaimus & 2 & $-26.1 \pm 5.7$ & & \\
\hline Paracanthonchus & 1 & -29.8 & & \\
\hline Paracomesoma & 4 & $-20.0 \pm 1.5$ & 2 & $7.6 \pm 2.1$ \\
\hline Sabatieria sp. 1 & 3 & $-21.1 \pm 0.7$ & & \\
\hline Sabatieria sp. 2 & 1 & -28.6 & & \\
\hline Sphaerolaimus & 1 & -23.7 & 1 & 7.5 \\
\hline Spirinia parasitifera & 3 & $-27.5 \pm 6.2$ & 1 & 4.1 \\
\hline Spirinia sp.2 & 3 & $-15.9 \pm 0.6$ & 3 & $5.9 \pm 1.1$ \\
\hline Terschellingia & 6 & $-40.4 \pm 4.5$ & 1 & 3.2 \\
\hline Bulk Nematoda & 8 & $-22.3 \pm 3.5$ & 2 & 6.5 \\
\hline \multicolumn{5}{|l|}{ COPEPODA } \\
\hline Cletodidae & 1 & -33.5 & & \\
\hline Harpacticidae & 1 & -27.0 & & \\
\hline Sunaristes (Canuellidae) & 1 & -15.9 & & \\
\hline Bulk Copepoda & 7 & $-22.7 \pm 3.9$ & & \\
\hline
\end{tabular}

formation and through the enhancement of SPOM sedimentation (Ouisse et al., 2012). However, seagrass detritus and SPOM are also exported from seagrass beds to adjacent or even more distant locations (Hemminga et al., 1994; Heck et al., 2008). Our results support the idea that carbon inputs associated with seagrass beds extend beyond the vegetation boundaries and contribute to the diet of benthos living adjacent to seagrass vegetation, including representatives of the predominant meiofaunal taxa.

Fresh seagrass leaves and roots, despite their biomass, are generally considered of minor importance as carbon resources for the benthos, mainly as a consequence of their poor nutritional value and high lignocellulose content (Ott and Maurer, 1977; Vizzini et al., 2002a). This is also supported by the results of our study, where the majority of meiofaunal taxa were considerably more depleted in $\delta^{13} \mathrm{C}$ than seagrass tissue. Nevertheless, the high contribution of seagrass carbon predicted by the mixing model and the relatively enriched $\delta^{13} \mathrm{C}$ for some nematode genera (i.e. Daptonema, Theristus, Metachromadora, Spirinia sp. 2 and Ptycholaimellus) suggest that they depend to a considerable extent on seagrass-derived carbon. Based on mouthmorphology derived assumptions on their feeding ecology, these nematode genera have usually been considered MPB feeders. Our present $\delta^{13} \mathrm{C}$ data do not point at a major contribution of MPB in the diet of these nematodes. In contrast, they clearly indicate that they utilize Zostera detritus, either directly or through grazing on detritivorous (micro)organisms. In addition, exudates secreted by seagrass roots may be directly or indirectly utilized by meiofauna, for instance, through grazing on bacteria. However, Boschker et al. (2000) found no significant transfer of labelled carbon from living seagrass tissues to benthic bacteria through root exudation. Hence, our data suggest that several abundant nematode genera utilize seagrass detritus and/or its associated micro-organisms.

The predominant aboveground associates of seagrass are epiphytic microalgae, which can contribute significantly to the primary production in seagrass beds, and have a generally high nutritional value (Kitting et al., 1984; Gambi et al., 1992; Moncreiff and Sullivan, 2001). In our study, they had considerably more depleted carbon isotope signatures than fresh or detrital seagrass material and a variety of meiofauna, in particular, several epistratum-feeding nematodes and harpacticoid copepods, had $\delta^{13} \mathrm{C}$ values closely resembling those of epiphytes. Given the expected importance of microalgae as food to many harpacticoid copepods (De Troch et al., 2005a, b) and epistratum-feeding nematodes (Moens and Vincx, 1997), it is tempting to interpret these results as an important utilization of seagrass epiphytes by meiofauna. However, the carbon isotope signatures of epiphytes in our study overlap with those of MPB, rendering firm conclusions on the relative importance of these resources difficult (see Vafeiadou et al., 2013a). Since larger seagrass fragments were very scant on bare sediments, it is nevertheless unlikely that epiphytes would have substantially contributed to nematode diets in these bare sediments. Given the absence of significant differences in nematode isotope signatures between vegetated and bare sediments, we therefore conclude that MPB and not epiphytes is probably the most important carbon resource for these nematodes, independent of the habitat where they were collected.

Indeed, the few studies which have previously looked at resource utilization of intertidal meiofauna at genus or species level have all stressed the importance of MPB as a principal food resource (Carman and Fry, 2000; Moens et al., 2002, 2005, 2013; Rzeznik-Orignac et al., 2008; Maria et al., 2012). A number of epistratum- and deposit-feeding nematodes in our study had intermediate carbon isotope signatures, suggesting they indeed feed predominantly on MPB and/or epiphytes. However, we cannot exclude that they utilize a mix of more ${ }^{13} \mathrm{C}$-depleted (e.g. SPOM) and more ${ }^{13} \mathrm{C}$ enriched (e.g. seagrass detritus) food resources, which would equally result in intermediate carbon isotopic signatures.

Given the increased sedimentation in seagrass beds, and the high contribution of SPOM in intertidal areas which are characterised by higher sedimentation (Moens et al., 2005), we expected SPOM to be a comparatively more important carbon resource for meiofauna inside Zostera patches than in bare sediments in our study area. The carbon isotope signatures of SPOM in our study were clearly more depleted than those of the other potential resources, and in the range of "typical" values for SPOM (comparing with SPOM data from the Mondego estuary, Portugal; Baeta et al., 2009 and from the Scheldt estuary, the Netherlands; Moens et al., 2005). This was not, however, reflected in more depleted $\delta^{13} \mathrm{C}$ signatures of meiofauna inside seagrass vegetation. 
Table 3. Proportional contributions per unit of each resource to the carbon requirements of meiofauna taxa in seagrass beds and bare sediments, in the surface $(2 \mathrm{~cm})$ and deeper sediments $(2-6 \mathrm{~cm})$, as computed by the isotope mixing model MixSIR (values given as median and lower to upper limits of $95 \%$ confidence intervals). MPB stands for microphytobenthos and SPOM for suspended particulate organic matter.

\begin{tabular}{|c|c|c|c|c|}
\hline \multicolumn{5}{|c|}{ Proportional contribution of resources } \\
\hline Consumers & $\begin{array}{l}\text { Seagrass roots } \\
\text { and detritus }\end{array}$ & Epiphytes and MPB & SPOM & $\begin{array}{l}\text { Chemoautotrophic } \\
\text { bacteria }\end{array}$ \\
\hline \multicolumn{5}{|c|}{ Seagrass beds (upper $2 \mathrm{~cm}$ ) } \\
\hline Anoplostoma & $0.32(0.04-0.64)$ & $0.18(0.01-0.65)$ & $0.26(0.02-0.69)$ & $0.13(0.02-0.31)$ \\
\hline Comesomatidae & $0.34(0.05-0.63)$ & $0.22(0.02-0.66)$ & $0.24(0.02-0.62)$ & $0.12(0.01-0.28)$ \\
\hline Daptonema & $0.70(0.48-0.87)$ & $0.14(0.01-0.42)$ & $0.08(0.01-0.26)$ & $0.04(0.00-0.13)$ \\
\hline Metachromadora & $0.75(0.60-0.88)$ & $0.12(0.01-0.31)$ & $0.08(0.01-0.21)$ & $0.03(0.00-0.09)$ \\
\hline Paracanthonchus & $0.36(0.06-0.66)$ & $0.18(0.01-0.66)$ & $0.24(0.02-0.65)$ & $0.11(0.01-0.28)$ \\
\hline Paracomesoma & $0.25(0.03-0.51)$ & $0.14(0.01-0.48)$ & $0.29(0.03-0.73)$ & $0.25(0.09-0.40)$ \\
\hline Sabatieria sp. 1 & $0.30(0.04-0.60)$ & $0.19(0.02-0.63)$ & $0.27(0.02-0.68)$ & $0.14(0.02-0.32)$ \\
\hline Sphaerolaimus & $0.39(0.07-0.59)$ & $0.08(0.01-0.31)$ & $0.27(0.02-0.75)$ & $0.22(0.04-0.35)$ \\
\hline Spirinia parasitifera & $0.29(0.03-0.60)$ & $0.11(0.01-0.54)$ & $0.37(0.25-0.78)$ & $0.15(0.02-0.33)$ \\
\hline Spirinia sp. 2 & $0.59(0.28-0.81)$ & $0.16(0.01-0.58)$ & $0.12(0.01-0.38)$ & $0.06(0.01-0.13)$ \\
\hline Terschellingia & $0.02(0.00-0.08)$ & $0.02(0.00-0.08)$ & $0.03(0.00-0.10)$ & $0.91(0.83-0.97)$ \\
\hline Cletodidae & $0.12(0.01-0.33)$ & $0.10(0.01-0.33)$ & $0.15(0.01-0.47)$ & $0.55(0.39-0.74)$ \\
\hline \multicolumn{5}{|c|}{ Seagrass beds (deeper sediments: $2-6 \mathrm{~cm}$ ) } \\
\hline Paracomesoma & $0.46(0.14-0.72)$ & $0.22(0.02-0.67)$ & $0.17(0.02-0.47)$ & $0.07(0.01-0.22)$ \\
\hline Sphaerolaimus & $0.20(0.02-0.49)$ & $0.14(0.01-0.51)$ & $0.28(0.02-0.73)$ & $0.28(0.10-0.48)$ \\
\hline Spirinia sp. 2 & $0.72(0.52-0.85)$ & $0.06(0.01-0.27)$ & $0.11(0.01-0.35)$ & $0.07(0.01-0.17)$ \\
\hline Terschellingia & $0.03(0.00-0.11)$ & $0.03(0.00-0.10)$ & $0.04(0.00-0.13)$ & $0.89(0.78-0.96)$ \\
\hline Consumers & $\begin{array}{l}\text { Seagrass roots } \\
\text { and detritus }\end{array}$ & Epiphytes and MPB & SPOM & $\begin{array}{l}\text { Chemoautotrophic } \\
\text { bacteria }\end{array}$ \\
\hline \multicolumn{5}{|c|}{ Bare sediments (upper $2 \mathrm{~cm}$ ) } \\
\hline Daptonema & $0.71(0.31-0.89)$ & $0.16(0.01-0.60)$ & $0.07(0.01-0.23)$ & $0.03(0.00-0.09)$ \\
\hline Metachromadora & $0.85(0.70-0.95)$ & $0.07(0.01-0.23)$ & $0.04(0.00-0.13)$ & $0.01(0.00-0.05)$ \\
\hline Paracomesoma & $0.39(0.06-0.69)$ & $0.06(0.00-0.31)$ & $0.39(0.02-0.78)$ & $0.12(0.01-0.27)$ \\
\hline Sphaerolaimus & $0.52(0.10-0.71)$ & $0.07(0.01-0.42)$ & $0.20(0.01-0.72)$ & $0.16(0.01-0.26)$ \\
\hline Spirinia parasitifera & $0.34(0.04-0.65)$ & $0.11(0.01-0.53)$ & $0.34(0.02-0.76)$ & $0.14(0.02-0.28)$ \\
\hline Spirinia sp. 2 & $0.67(0.25-0.86)$ & $0.15(0.01-0.63)$ & $0.10(0.01-0.30)$ & $0.04(0.00-0.12)$ \\
\hline Terschellingia & $0.02(0.00-0.06)$ & $0.02(0.00-0.07)$ & $0.02(0.00-0.08)$ & $0.93(0.86-0.97)$ \\
\hline Sunaristes(Canuellidae) & $0.64(0.20-0.84)$ & $0.14(0.01-0.66)$ & $0.11(0.01-0.35)$ & $0.05(0.00-0.14)$ \\
\hline \multicolumn{5}{|c|}{ Bare sediments (deeper sediments: $2-6 \mathrm{~cm}$ ) } \\
\hline Paracomesoma & $0.29(0.03-0.64)$ & $0.15(0.01-0.64)$ & $0.31(0.02-0.75)$ & $0.14(0.02-0.30)$ \\
\hline Spirinia parasitifera & $0.23(0.02-0.59)$ & $0.14(0.01-0.59)$ & $0.34(0.02-0.79)$ & $0.17(0.03-0.35)$ \\
\hline
\end{tabular}

Isotopic signatures reflecting utilization of SPOM were most prominent in the nematodes Spirinia parasitifera, Sabatieria sp. 2, Oncholaimus, Sphaerolaimus and Paracomesoma, and in the copepod family Harpacticidae from deeper sediments $(2-6 \mathrm{~cm})$. This was the case in both vegetated and bare sediments, except for Oncholaimus and Harpacticidae which occurred only in seagrass beds. The increased contributions of SPOM for the nematodes Sphaerolaimus, Paracomesoma and Spirinia parasitifera also confirm their reliance on this carbon resource. However, according to their elevated $\delta^{15} \mathrm{~N}$, the first two of these genera utilize SPOM indirectly, probably through feeding on prey which rely on SPOM. Alternatively, it is also possible that the abundant genus Terschellingia is among their prey and therefore, indirect reliance on chemosynthetic bacteria is also possible. This is also indicated by the predicted contributions of the latter resource for these two nematode genera. In general, modelled contributions of SPOM are considerably higher when chemoautotrophic carbon is not included as a resource in the mixing model. 
Furthermore, our data highlight differential resource utilization between surface $(2 \mathrm{~cm})$ and deeper sediment layers $(2-6 \mathrm{~cm})$, indicating a shift towards a higher SPOM contribution in deeper sediments for the nematodes Anoplostoma, Bathylaimus, Oncholaimus, Paracanthonchus, Sphaerolaimus and Spirinia parasitifera and for the copepod family Harpacticidae. Hence, our data partly support Rudnick's (1989) hypothesis of differential resource utilization by surface-inhabiting vs. deeper-dwelling meiofauna. Surface food-addition experiments in subtidal (Ólafsson et al., 1999) and intertidal (Moens et al., 2002) sediments have also demonstrated that nematodes from both surface and deeper sediment layers can consume deposited phytodetritus. However, our results do not support Rudnick's (1989) contention that deeper-dwelling nematodes rely more on refractory organic matter. Among the resources considered in the present study, seagrass detritus is the most refractory, but our data indicate that it is utilized less rather than more by deeperdwelling nematodes.

The strongly depleted $\delta^{13} \mathrm{C}$ values of the nematode Terschellingia and the copepod family Cletodidae demonstrate utilization of a carbon resource not included in our sampling. Several chemoautotrophic processes yield highly depleted $\delta^{13} \mathrm{C}$ values. Among them is sulfide oxidation; sulfideoxidizing bacteria have $\delta^{13} \mathrm{C}$ values which tend to be (well) below $-30 \%$ (Robinson and Cavanaugh, 1995). Hence, our results strongly indicate that Terschellingia and Cletodidae rely predominantly or even exclusively on such bacteria, as also supported by the high contributions predicted by the mixing model.

Our data for Terschellingia are consistent with previous records $\left(\delta^{13} \mathrm{C}=-43 \%\right.$ ) from a mangrove ecosystem (T. Moens, unpublished data; in Bouillon et al., 2008) and from an estuarine intertidal flat in the Oosterschelde, the Netherlands (Moodley et al., unpublished data; in Moens et al., 2011). Terschellingia is a microvore with a very small buccal cavity, enabling ingestion of only bacteria-sized particles, and tends to be very abundant in hypoxic/anoxic sediments (Steyaert et al., 2007), where chemosynthetic processes can be important. The nematode genera Terschellingia and Sabatieria have been suggested to feed on sulfideoxidizing bacteria in deep-sea sediments too (Pape et al., 2011; Guilini et al., 2012). Sabatieria sp. 2 in our study also had depleted $\delta^{13} \mathrm{C}(-23.4 \%$ and $-28.3 \%$ in vegetated and bare sediments, respectively). These data suggest that Sabatieria sp. 2 partly relies on chemoautotrophic carbon, especially in bare sediments; in contrast, Sabatieria sp. 1 was more enriched than its congener and probably depends largely on MPB.

Little is known on the autecology and feeding habits of Cletodidae copepods (Hicks and Coull, 1983), but diatoms, detritus and bacteria have all been listed as their food resources (Ivester and Coull, 1977). However, recent data from a salt marsh gully in the Scheldt estuary, the Netherlands, confirm our results that sulfide-oxidizing bacteria are the ma- jor carbon resource for these copepods (Cnudde et al., 2014). Further, Grego et al. (2014) found representatives of the family Cletodidae to be the most resistant copepods to longterm anoxia. Apart from a single mention of equally depleted $\delta^{13} \mathrm{C}$ of an unidentified harpacticoid copepod from the Oosterschelde estuary (Moens et al., 2011), these data provide the first evidence of a trophic association between harpacticoid copepods and chemoautotrophic bacteria. Whether this association involves (selective) grazing on chemoautotrophic bacteria or some form of symbiosis remains unknown, both for the Cletodidae and for Terschellingia. In contrast to nematodes belonging to the Stilbonematinae (Ott et al., 1991), neither Terschellingia nor Cletodidae show obvious signs of ectosymbiotic micro-organisms. The possibility of an endosymbiotic relationship remains to be investigated.

\subsection{Implications for nematode trophic guild classifications}

A clear distinction among trophic levels within the meiofauna analysed here is evident from the stable nitrogen isotope data, with Sphaerolaimus, Paracomesoma and unidentified Comesomatidae belonging to a higher trophic level than all other nematodes and harpacticoid copepods. Our results on Sphaerolaimus are in agreement with trophic guild classifications based on mouth morphology (Moens and Vincx, 1997), and with results from a stable isotope study from the Scheldt estuary, the Netherlands (Moens et al., 2005) and from a mudflat in Marennes-Oléron bay, on the French Atlantic coast (Rzeznik-Orignac et al., 2008). Furthermore, predation by Sphaerolaimus may be selective, since its relatively depleted carbon isotope signatures poorly reflect those of the majority of its candidate prey species. On the other hand, the $\delta^{13} \mathrm{C}$ of Sphaerolaimus may also result from predation on Terschellingia in addition to feeding on other prey species.

A predatory feeding ecology for Paracomesoma and unidentified Comesomatidae is, however, counter to expectations. Comesomatidae are generally considered deposit feeders (Wieser, 1953; Moens and Vincx, 1997), the prime food resources of which in intertidal and shallow subtidal sediments are often microalgae and prokaryotes (Wieser, 1953; Moens and Vincx, 1997; Moens et al., 2005). However, buccal cavities without teeth or tooth-like structures may still serve predatory strategies through ingestion of whole prey (Moens and Vincx, 1997), and a variety of ciliates and flagellates may potentially serve as first-level consumers which could be preyed upon by nematodes such as Paracomesoma. Similarly, Moens et al. (2005) found an unexpectedly high $\delta^{15} \mathrm{~N}$ for Ascolaimus elongatus; they also mentioned an unpublished observation of another comesomatid, Sabatieria, regurgitating ciliates upon addition of a chemical fixative. Hence, we suggest that Paracomesoma and unidentified Comesomatidae obtain most of their carbon through predation on heterotrophic protists or other small prey which in turn depend on various resources. 
The nematode genera Daptonema and Theristus are considered non-selective deposit feeders (Wieser, 1953) or deposit feeders, which ingest suitably sized food particles like microalgae cells (Jensen, 1987; Moens and Vincx, 1997). Diatom grazing has been reported as a main feeding strategy for Daptonema from temperate tidal flats, based on observations (Nehring, 1990; Moens and Vincx, 1997) as well as on natural stable carbon isotope signatures (Carman and Fry, 2002; Moens et al., 2002; Rzeznik-Orignac et al., 2008). Nevertheless, the stable isotope signatures of Spartina sp. and MPB are often in the same range; thus, discrimination between the utilization of these two resources based on stable carbon isotopes can be difficult (see also Couch, 1989). In light of the present results, which show that Daptonema can utilize vascular plant detritus, caution is due when discarding vascular-plant derived detrital resources from the diet of this and other nematodes. Documentation of the feeding behaviour of intertidal Theristus is sparser than for Daptonema, but here too, diatoms have been shown to be a prominent food resource based on observations and on stable isotope data (Boucher, 1973; Moens et al., 2013). In general, however, (non-selective) deposit feeders are considered opportunistic feeders capable of ingesting a variety of food particles, including microalgae, bacteria, and perhaps also small detrital particles, the latter also being indicated by the results of this study, with particle size being a major determinant of food selection (Moens and Vincx, 1997).

A strong link between the genera Metachromadora and Ptycholaimellus and seagrass detritus was unexpected. Both genera were originally considered predators based on their mouth morphology (Wieser, 1953), but observations on feeding behaviour (Moens and Vincx, 1997) and stable isotope data (Moens et al., 2002, 2005) have shown that they can predominantly rely on MPB in intertidal flats. As epistrate feeders, they utilize a tooth to pierce food particles before emptying them, or to scrape off epigrowth from sediment or detrital particles. The present results, however, suggest that they may also utilize microbes associated with vascular plant detritus, a trophic link also suggested for Ptycholaimellus and Spartina alterniflora (Loisel.) in salt marsh sediments (Carman and Fry, 2002). Such differences between studies may point at a considerable flexibility in resource utilization (Moens et al., 2004). In any case, these results highlight that the idea that epistratum-feeding nematodes from intertidal and shallow subtidal sediments primarily utilize microalgae cannot be generalized.

Thus, we found unexpected resource utilization patterns for some deposit and epistrate feeders. In addition, we observed considerable variation in both resource use and trophic level among genera from the same feeding type (e.g. Paracomesoma, Sabatieria and unidentified Comesomatidae), showing that stoma morphology-based classifications provide very artificial functional groupings. It must be noted that all the resources considered in the present study are composed of different species (for instance for MPB/epiphytes) or compounds (for instance different tissues and "chemical" composition in seagrass detritus), which may exhibit differences in isotopic signature. Rzeznik-Orignac et al. (2008), for instance, found small differences $\left(\sim 1-2 \%\right.$ ) in $\delta^{13} \mathrm{C}$ between different size groups of MPB. Selective consumption of specific taxa or compounds in a resource class, or of microbes which have selectively assimilated specific compounds, may affect any interpretation of resource utilization using broadly defined resources as we have done here. Such a level of understanding would require the use of pulsechase experiments and compound-specific rather than bulk tissue isotopic analyses (Boschker and Middelburg, 2002; De Troch et al., 2012). Nevertheless, considering the strong variation of isotope data among confamiliar and even congeneric species (as observed for Comesomatidae, the two Sabatieria species and the two Spirinia species in the present study), we strongly recommend avoiding interpretation of meiofaunal resource use and even trophic level at suprageneric levels, and emphasize that resource use may be highly speciesspecific. Hence, we clearly demonstrate that the traditional feeding type classifications of nematodes based on buccal morphology can be misleading and should be combined with empirical information for reliable conclusions.

\section{Summary}

The organic carbon inputs in the benthic food web in seagrass beds at the Mira estuary derive from various resources, namely seagrass detritus, roots, epiphytes, MPB and SPOM, all to some extent being utilized by nematodes and harpacticoid copepods. In addition, chemoautotrophic carbon is also included in the diet of some taxa, most probably via feeding on sulfide-oxidizing bacteria. Seagrass detritus is available also in the bare sediments adjacent to seagrass beds, as well as in deeper layers, demonstrating the important role of seagrass-derived carbon for the estuarine benthos. The predatory feeding mode suggested for the expected depositfeeding Comesomatidae, in addition to the considerable variation in both resource use and trophic level found for confamiliar or congeneric nematode species, clearly demonstrate that the traditional feeding type classifications based on the mouth morphology of nematodes can be strongly misleading. Therefore, we recommend combining mouth morphology with stable isotope analysis at the genus or even species level in order to clarify the complex feeding interactions at/near the basis of the benthic food web.

Acknowledgements. The authors acknowledge financial support from the Flemish Science Foundation FWO through project 3G.0192.09 and from the research council of Ghent University through projects BOF-GOA 01GA1911 W and BOF0110600002. $\mathrm{M}$. De Troch is a postdoctoral researcher financed by the latter project. We are grateful to Frank Dehairs for access to the stable isotope facilities of the Department of Analytical and 
Environmental Chemistry of the Free University Brussels, and to David Verstraeten and Leen Rymenans for technical assistance during stable isotope measurements.

Edited by: G. Herndl

\section{References}

Adão, H., Alves, A. S., Patrício, J., Neto, J. M., Costa, M. J., and Marques, J. C.: Spatial distribution of subtidal Nematoda communities along the salinity gradient in southern European estuaries, Acta Oecol., 35, 287-300, 2009.

Baeta, A., Pinto, R., Valiela, I., Richard, P., Niquil, N., and Marques, J. C.: $\delta^{15} \mathrm{~N}$ and $\delta^{13} \mathrm{C}$ in the Mondego estuary food web: Seasonal variation in producers and consumers, Mar. Environ. Res., 67, 109-116, 2009.

Boschker, H. T. S. and Middelburg, J. J.: Stable isotopes and biomarkers in microbial ecology, FEMS Microb. Ecol., 40, 8595, 2002.

Boschker, H. T. S., De Brouwer, J. F. C., and Cappenberg, T. E.: The contribution of macrophyte-derived organic matter to microbial biomass in salt-marsh sediments: Stable carbon isotope analysis of microbial biomarkers, Limnol. Oceanogr., 44, 309-319, 1999.

Boschker, H. T. S., Wielemaker, A., Schaub, B. E. M., and Holmer, M.: Limited coupling of macrophyte production and bacterial carbon cycling in the sediments of Zostera spp. Meadows, Mar. Ecol. Progr. Ser., 203, 181-189, 2000.

Boström, C. and Bonsdorff, E.: Community structure and spatial variation of benthic invertebrates associated with Zostera marina (L.) beds in the northern Baltic Sea, J. Sea Res., 37, 153-166, 1997.

Boucher, G: Premières données écologiques sur les nematodes libres marins d'une station de vase côtière de Banyuls, Vie Milieu Ser. B Oceanogr., 23, 69-100, 1973.

Bouillon, S., Connolly, R., and Lee, S. Y.: Organic matter exchange and cycling in mangrove ecosystems: recent insights from stable isotope studies, J. Sea Res., 59, 44-58, 2008.

Carlier, A., Riera, P., Amouroux, J. M., Bodiou, J. Y., Desmalades, M., and Grémare, A.: Spatial heterogeneity in the food web of a heavily modified Mediterranean coastal lagoon: stable isotope evidence, Aquat. Biol., 5, 167-179, 2009.

Carman, K. R. and Fry, B.: Small-sample methods for $\delta^{13} \mathrm{C}$ and $\delta^{15} \mathrm{~N}$ analysis of the diets of marsh meiofaunal species using natural-abundance and tracer-addition isotope techniques, Mar. Ecol. Progr. Ser., 240, 85-92, 2002.

Cnudde, C., Moens, T., Willems, A., and De Troch, M.: Substratedependent bacterivory by intertidal benthic copepods, Mar. Biol., 160, 327-341, 2013.

Cnudde, C., Werbrouck, E., Lepoint, G., Vangansbeke, D. Moens, T., and De Troch, M.: Trophodynamics of estuarine intertidal harpacticoid copepod species based on stable isotope composition and fatty acid profiles, Mar. Ecol. Progr. Ser., under revision, 2014.

Costa, M. J., Catarino, F., and Bettencourt, A.: The role of salt marshes in the Mira estuary (Portugal), Wetl. Ecol. Manag., 9, 121-134, 2001.

Cunha, A. H., Assis, J., and Serrão, E.: Seagrass in Portugal: A most endangered marine habitat, Aquat. Bot., 104, 193-203, 2013.
De Troch, M., Steinarsdóttir, M. B., Chepurnov, V., and Ólafsson, E.: Grazing on diatoms by harpacticoid copepods: speciesspecific density-dependent uptake and microbial gardening, Aquat. Microb. Ecol., 39, 135-144, 2005a.

De Troch, M., Vandepitte, L., Raes, M., Suàrez-Morales, E., and Vincx, M.: A field colonisation experiment with meiofauna and seagrass mimics: effect of time, distance and surface, Mar. Biol. 148, 73-86, 2005b.

De Troch, M., Chepurnov, V., Gheerardyn, H., Vanreusel, A., and Ólafsson, E.: Is diatom size selection by harpacticoid copepods related to grazer body size?, J. Exp. Mar. Biol. Ecol., 332, 1-11, 2006.

De Troch, M., Boeckx, P., Cnudde, C., Van Gansbeke, D., Vanreusel, A., Vincx, M., and Caramujo, M. J.: Bioconversion of fatty acids at the basis of marine food webs: insights from a compound-specific stable isotope analysis, Mar. Ecol. Progr. Ser., 465, 53-67, 2012.

Eaton, J. W. and Moss, B.: The estimation of numbers and pigment content in epipelic algal populations, Limnol. Oceanogr., 11, 584-595, 1966.

Edgar, G. J., Shaw, C., Watson, G. F., and Hammond, L. S.: Comparisons of species richness, size structure and productions of benthos in vegetated and unvegetated habitats in Western Port, Victoria, J. Exp. Mar. Biol. Ecol., 176, 201-226, 1994.

Ferrell, D. J. and Bell, J. D.: Differences among assemblages of fish associated with Zostera capricorni and bare sand over a large spatial scale, Mar. Ecol. Progr. Ser., 72, 15-24, 1991.

Fonseca, M. S. and Fisher, J. S.: A comparison of canopy friction and sediment movement between four species of seagrass with reference to their ecology and restoration, Mar. Ecol. Progr. Ser., 29, 15-22, 1986.

Gambi, M. C., Lorenti, M., Russo, G. F., Scipione, M. B., and Zupo, V.: Depth and seasonal distribution of some groups of the vagile fauna of the Posidonia oceanica leaf stratum: structural and trophic analyses, Mar. Ecol., 13, 17-39, 1992.

Grego, M., Riedel, B., Stachowitsch, M., and De Troch, M.: Meiofauna winners and losers of coastal hypoxia: case study harpacticoid copepods, Biogeosciences, 11, 281-292, doi:10.5194/bg11-281-2014, 2014.

Guilini, K., Levin, L. A., and Vanreusel, A.: Cold seep and oxygen minimum zone associated sources of margin heterogeneity affect benthic assemblages, diversity and nutrition at the Cascadian margin (NE Pacific Ocean), Prog. Oceanogr., 96, 77-92, 2012.

Heck, K. L., Able, K. W., Fahay, M. P., and Roman, C. T.: Fishes and decapod crustaceans of Cape Cod eelgrass meadows: species composition, seasonal abundance patterns and comparison with unvegetated substrates, Estuaries, 12, 59-65, 1989.

Heck Jr., K. L., Carruthers, T. J., Duarte, C. M., Hughes, A. R., Kendrick, G., Orth, R. J., and Williams, S. W.: Trophic transfers from seagrass meadows subsidize diverse marine and terrestrial consumers, Ecosystems, 11, 1198-1210, 2008.

Hemminga, M. A. and Duarte, C. M. (Eds): Seagrass Ecology, Cambridge University Press, Cambridge, 298 pp., 2000.

Hemminga, M. A., Slim, F. J., Kazungu, J., Ganssen, G. M., Nieuwenhuize, J., and Kruyt, N. M.: Carbon outwelling from a mangrove forest with adjacent seagrass beds and coral reefs (Gazi Bay, Kenya), Mar. Ecol. Progr. Ser., 106, 291-301, 1994.

Hicks, G. R. F. and Coull, B. C.: The ecology of marine meiobenthic harpacticoid copepods, Oceanogr Mar. Biol., 21, 67-175, 1983. 
Ivester, M. S. and Coull, B. C.: Niche fractionation studies of two sympatric species of Enhydrosoma (Copepoda, Harpacticoida), Microfauna Meeresboden, 61, 137-151, 1977.

Jensen, P.: Feeding ecology of free-living aquatic nematodes, Mar. Ecol. Progr. Ser., 35, 187-196, 1987.

Kharlamenko, V. I., Kiyashko, S. I., Imbs, A. B., and Vyshkvartzev, D. I.: Identification of food sources of invertebrates from the seagrass Zostera marina community using carbon and sulphur stable isotope ratio and fatty acid analyses, Mar. Ecol. Progr. Ser., 220, 103-117, 2001.

Kitting, C. L., Fry, B., and Morgan, M. D.: Detection of inconspicuous epiphytic algae supporting food webs in seagrass meadows, Oecologia, 62, 145-149, 1984.

Lebreton, B., Richard, P., Galois, R., Radenac, G., Pfléger, C., Guillou, G., Mornet, F., and Blanchard, G. F.: Trophic importance of diatoms in an intertidal Zostera noltii seagrass bed: Evidence from stable isotope and fatty acid analyses, Estuar. Coast. Shelf Sci., 92, 140-153, 2011.

Lebreton, B., Richard, P., Galois, R., Radenac, G., Brahmia, A., Colli, G., Grouazel, M., André, C., Guillou, G., and Blanchard, G. F.: Food sources used by sediment meiofauna in an intertidal Zostera noltii seagrass bed: a seasonal stable isotope study, Mar. Biol., 159, 1537-1550, 2012.

Leduc, D. and Probert, P. K.: The effect of bacterivorous nematodes on detritus incorporation by macrofaunal detritivores: A study using stable isotope and fatty acid analyses, J. Exp. Mar. Biol. Ecol., 371, 130-139, 2009.

Lepoint, G., Nyssen, F., Gobert, S., Dauby, P., and Bouquegneau, J. M.: Relative impact of a seagrass bed and its adjacent epilithic algal community in consumer diets, Mar. Biol., 136, 513-518, 2000.

Maria, T. F., Vanaverbeke, J., Esteves, A. M., De Troch, M., and Vanreusel, A.: The importance of biological interactions for the vertical distribution of nematodes in a temperate ultra-dissipative sandy beach, Estuar. Coast. Shelf Sci., 97, 114-126, 2012.

Middelburg, J. J.: Stable isotopes dissect aquatic food webs from the top to the bottom, Biogeosciences, 11, 2357-2371, doi:10.5194/bg-11-2357-2014, 2014.

Moens, T. and Vincx, M: Observations on the feeding ecology of estuarine nematodes, J. Mar. Biol. Ass. UK, 77, 211-227, 1997.

Moens, T., Luyten, C., Middelburg, J. J., Herman, P. M. J., and Vincx, M.: Tracing organic matter sources of estuarine tidal flat nematodes with stable carbon isotopes, Mar. Ecol. Progr. Ser., 234, 127-137, 2002.

Moens, T., Yeates, G., and De Ley, P.: Use of carbon and energy sources by nematodes, in: Proceedings of the Fourth International Congress of Nematology, Tenerife, Spain, 8-13 June 2002, 529-545, 2004.

Moens, T., Bouillon, S., and Gallucci, F.: Dual stable isotope abundances unravel trophic position of estuarine nematodes, J. Mar. Biol. Ass. UK, 85, 1401-1407, 2005.

Moens, T., Moodley, L., Steyaert, M., Van Colen, C., Van Oevelen, D., Boschker, H. T., Herman, P. J. M., Middelburg, J. J., Soetaert, K., Ysebaert, T., and Vincx, M.: The structure and functional roles of tidal flat meiobenthos, in: Aspects of coastal research in contribution to LOICZ in the Netherlands and Flanders (20022010), edited by: Heip, C. and Laane, R., LOICZ Research and Studies, 38, Helmholtz-Zentrum Geesthacht, Germany, 184 pp., 2011.
Moens, T., Vafeiadou, A. M., De Geyter, E., Vanormelingen, P., Sabbe, K., and De Troch, M.: Diatom feeding across trophic guilds in tidal flat nematodes, and the importance of diatom cell size, J. Sea Res., published online at: doi:10.1016/j.seares.2013.08.007, 2013.

Moncreiff, C. A. and Sullivan, M. J.: Trophic importance of epiphytic algae in subtropical seagrass beds: evidence from multiple stable isotope analyses, Mar. Ecol. -Progr. Ser., 215, 93-106, 2001.

Nehring, S., Jensen, P., and Lorenzen, S.: Tube-dwelling nematodes: tube construction and possible ecological effects on sediment-water interfaces, Mar. Ecol. Progr. Ser., 64, 123-128, 1990.

Ólafsson, E., Modig, H., and van de Bund, W. J.: Species specific uptake of radio-labelled phytodetritus by benthic meiofauna from the Baltic Sea, Mar. Ecol. Progr. Ser., 177, 63-72, 1999.

Ott, J. A. and Maurer, L.: Strategies of energy transfer from marine macrophytes to consumer levels: the Posidonia oceanica example, in: Biology of Benthic Organisms, edite by: Keegan, B. F., O'Ceidigh, P., and Boaden, P. J. S., Pergamon Press, New York, 493-502, 1977.

Ott, J. A., Novak, R., Schiemer, F., Hentschel, U., Nebelsick, M., and Polz, M.: Tackling the sulfide gradient: a novel strategy involving marine nematodes and chemoautotrophic ectosymbionts, Mar. Ecol., 12, 261-279, 1991.

Ouisse, V., Riera, P., Migné, A., Leroux, C., and Davoult, D.: Food web analysis in intertidal Zostera marina and Zostera noltii communities in winter and summer, Mar. Biol., 159, 165-175, 2012.

Pape, E., Bezerra, T. N. C., Vanneste, H., Heeschen, K., Moodley, L., Leroux, F., van Breugel, P., and Vanreusel, A.: Community structure and feeding preference of nematodes associated with methane seepage at the Darwin mud volcano (Gulf of Cádiz), Mar. Ecol. Progr. Ser., 438, 71-83, 2011.

Parnell, A. C., Inger, R., Bearhop, S., and Jackson, A. L.: Source partitioning using stable isotopes: coping with too much variation, PLoS ONE, 5, e9672, doi:10.1371/journal.pone.0009672, 2010.

Robinson, J. L. and Cavanaugh, C. M.: Rubisco in chemoautotrophic symbioses: Implications for the interpretation of stable carbon isotope values, Limnol. Oceanogr., 40, 1496-1502, 1995.

Rudnick, D. T.: Time lags between the deposition and meiobenthic assimilation of phytodetritus, Mar. Ecol. Progr. Ser., 50, 231240, 1989.

Rzeznik-Orignac, J., Boucher, G., Fichet, D., and Richard, P.: Stable isotope analysis of food source and trophic position of intertidal nematodes and copepods, Mar. Ecol. Progr. Ser., 359, 145-150, 2008.

Semmens, B. X. and Moore, J. W.: MixSIR: A Bayesian stable isotope mixing model. Version 1.0. EcologyBox, Mathematical Biology Program, Northwest Fisheries Science Center, Seattle, 2008.

Steyaert, M., Moodley, L., Nadong, T., Moens, T., Soetaert, K., and Vincx, M.: Responses of intertidal nematodes to short-term anoxic events, J. Exp. Mar. Biol. Ecol., 345, 175-184, 2007.

Vander Zanden, M. J. and Rasmussen, J. B.: Variation in $\delta^{15} \mathrm{~N}$ and $\delta^{13} \mathrm{C}$ trophic fractionation: implications for aquatic food web studies, Limnol. Oceanogr., 46, 2061-2066, 2001.

Vafeiadou, A. M., Materatski, P., Adão, H., De Troch, M., and Moens, T.: Food sources of macrobenthos in an estuarine sea- 
grass habitat (Zostera noltii) as revealed by dual stable isotope signatures, Mar. Biol., 160, 2517-2523, 2013a.

Vafeiadou, A. M., Adão, H., De Troch, M., and Moens, T.: Sample acidification effects on carbon and nitrogen stable isotope ratios of macrofauna from a Zostera noltii bed, Mar. Fresh. Res., 64, 741-745, 2013b.

Vizzini, S., Sarà, G., Michener, R. H., and Mazzola, A.: The role and contribution of the seagrass Posidonia oceanica (L.) Delile organic matter for secondary consumers as revealed by carbon and nitrogen stable isotope analysis, Acta Oecol., 23, 277-285, 2002a.
Vizzini, S., Sarà, G., Michener, R. H., and Mazzola, A.: The trophic role of the macrophyte Cymodocea nodosa (Ucria) Asch. in a Mediterranean saltworks: evidence from carbon and nitrogen stable isotope ratios, B. Mar. Sci., 71, 1369-1378, 2002 b.

Walker, D. I., Hillman, K. A., Kendrick, G. A., and Lavery, P.: Ecological significance of seagrasses: assessment for management of environmental impact in Western Australia, Ecol. Eng., 16, 323 330, 2001.

Wieser, W.: Die Beziehung zwischen Mundhöhlengestalt, Ernährungsweise und Vorkommen bei freilebenden marinen Nematoden, Arkiv für Zoologie, 4, 439-484, 1953. 